\title{
Section 16
}

\section{"Role of Coal in the World and Asia,"}

by Charles J. Johnson and Binsheng Li, presented at the First APEC

Coal Flow Seminar, October 4-6, 1994, Tokyo, Japan.

$$
\text { FCO3-94FE } 63313
$$




\section{$\$ 6619-t, 1090230$ \\ undur 0.6901}

THad pur LMW ใq parosuods

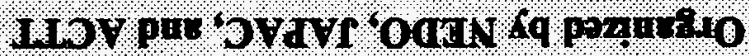

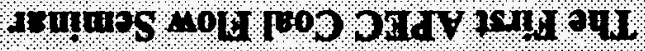

71 poluosold

\section{пвмвн 'прएоон}

IOLUPD $150 \mathrm{M}-15 \mathrm{~A}$

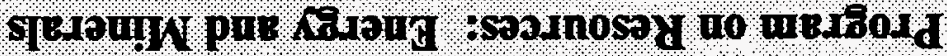

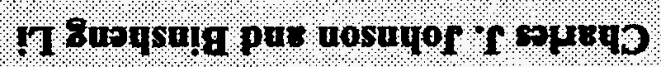

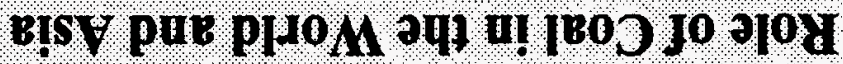

1-eEsolfib-Jrog 


\section{DISCLAIMER}

This report was prepared as an account of work sponsored by an agency of the United States Government. Neither the United States Government nor any agency thereof, nor any of their employees, make any warranty, express or implied, or assumes any legal liability or responsibility for the accuracy, completeness, or usefulness of any information, apparatus, product, or process disclosed, or represents that its use would not infringe privately owned rights. Reference herein to any specific commercial product, process, or service by trade name, trademark, manufacturer, or otherwise does not necessarily constitute or imply its endorsement, recommendation, or favoring by the United States Government or any agency thereof. The views and opinions of authors expressed herein do not necessarily state or reflect those of the United States Government or any agency thereof. 


\title{
Role of Coal in the World and Asia
}

\author{
Charles J. Johnson and Binsheng $\mathrm{Li}^{1}$
}

October, 1994

\section{Introduction}

This paper examines the changing role of coal in the world and in Asia. Particular attention is given to the rapidly growing demand for coal in electricity generation, the importance of China as a producer and consumer of coal, and the growing environmental challenge to coal. Attention is given to the increasing importance of low sulfur coal and Clean Coal Technologies in reducing the environmental impacts of coal burning.

\section{Coal's Role in the World and Asian Energy Mix}

Figure 1 shows the energy mix in world primary energy consumption. Fossil-fuels (oil, coal and natural gas) account for 90 percent of world primary energy consumption, with nuclear and hydropower accounting for the remaining 10 percent. Over the past 15 years, coal's share of world primary energy has varied from a high of 30 percent in the early 1980s to 27 percent in 1993.

As shown in Figure 2, the energy mix in Asia is quite different from the rest of the world. In Asia, coal accounts for 46 percent of primary energy consumption compared to 21 percent in the rest of the world. The second major difference is natural gas which accounts for only 8 percent of Asia's primary energy consumption compared to 28 percent for the rest of the world. ${ }^{2}$

The most important factor explaining Asia's greater dependence on coal is the impact of China-the world's largest coal producing and consuming economy. The relatively low share of natural gas in Asia is the combination of smaller gas reserves in Asia ( 7 percent of world reserves), less incentives to explore for gas in some economies, and lack of a developed pipeline network to move gas to markets. Even with accelerated development of natural gas in Asia,

\footnotetext{
${ }^{1} \mathrm{Dr}$. Johnson is head of the Coal Project, and $\mathrm{Dr}$. Li is a project fellow in the East-West Centers Program on Resources: Energy and Minerals, Honolulu, Hawaii. Ms. Amy J. Lamke, visiting fellow, assisted in the preparation of tables and figures for this paper. Coal Project research is partially supported by the Fossil Energy Office of the U.S. Department of Energy. Assumptions: Australia is included with Asia; lignite is excluded from coal figures; tons are metric tons; $\$$ are U.S. dollars; $1.0 t$ equals $\$ 0.01$.

${ }^{2}$ Noncommercial biomass energy is substantial in Asia, but is excluded from the energy statistics in this paper.
} 
gas is unlikely to account for more than $10-13$ percent of primary energy by 2010.

As shown in Figure 3, removing China from Asia's statistics, alters the shares in primary energy consumption as follows: coal falls to 28 percent, oil increases to an alarming 51 percent, and natural gas moves up to 12 percent.

\section{Coal's Major Markets and Trends}

There are many uses of coal including electricity generation, steel making, cement production, steam generation for industrial processes, chemicals, and residential heating and cooking. The two largest markets for coal are for electricity generation and steel making. Coal is classified into two broad categories: thermal coal is used for most applications, and metallurgical coal is used primarily in the steel industry. Historically, higher valued metallurgical coal dominated international coal trade. However, the combination of the petroleum crises of the 1970s, problems with nuclear power plants, and security of energy supply concerns of governments resulted in a shift toward greater reliance on thermal coal for electricity generation in the 1980s. As shown in Figure 4, thermal coal's share of international coal trade has increased from 44 percent in 1978 to 54 percent in 1993, and is projected to increase to about 65 percent in 2000.

The trends in coal consumption have varied widely among the different regions of the world over the past decade. As shown in Figure 5, over the 19831993 period, Asia accounted for about three-quarters of total world growth in coal consumption, with North America accounting for most of the remaining quarter. The major decline in coal consumption in non-OECD Europe is associated with the breakup of the former Soviet Union. Even though coal consumption in the former Soviet Union economies is expected to rebound, Asia is projected to remain the dominant growth region, accounting for 60-70 percent of the growth in world coal consumption over the 1993-2010 period.

\section{Coal's Role in Asia's Electricity Market}

The dominant growth area for coal consumption in the world and Asia is for thermal coal used to generate electricity. Electricity consumption correlates with the growth in gross domestic product (GDP). During the 1980s, ten of the twelve economies shown in Table 1, had electricity growth rates exceeding their GDP growth rates. The elasticities shown in Table 1 are the ratios of the GDP growth rates to electricity growth rates. Typically, electricity growth rates exceed GDP growth rates in developing economies (elasticity $>1.0$ ). For middle income developing economies (i.e. Malaysia, South Korea and Chinese Taipei) 
elasticities usually approach 1.0. Elasticities of less than 1.0 are typical of fully industrialized economies, such as Japan and the United States.

The projected electricity growth rates in Figure 6 assume a gradual decrease in GDP growth rates for most Asian economies over the 1993-2010 period, and gradually declining elasticities. The diagonal line in Figure 6 represents the points where the growth rates of electricity and GDP are equal (elasticity $=1.0)$.

China is an anomalous economy in Asia, as it has low per capita income and a low elasticity of about 0.8 . China's low elasticity is believed to be result of a combination of at least three factors: First, elasticity compares actual consumption of electricity with GDP, not the demand for electricity. In China, the demand for electricity is substantially higher than the amount of electricity supplied. Second, along with open door policies, beginning in the late-1970s, China began a shift away from energy intensive heavy industry toward less energy intensive light industry. Third, prior to the 1980s, energy prices in China were artificially very low, resulting in highly inefficient uses of electricity. The gradual introduction of price reforms in the 1980s has resulted in higher energy prices, and increased efforts to use energy more efficiently.

\section{Metallurgical Coal Markets}

The combination of declining rates of growth in steel production using blast furnaces and declining requirements of metallurgical coal per unit of steel result in stable or declining metallurgical coal consumption in most economies of the world. Seaborne trade in metallurgical coal is projected to remain approximately stable at 155-165 million tons per year for the rest of the 1990s. China is the largest exception to the worldwide trend. Chinese steel production is projected to increase from about 88 million tons in 1993 to 175 million tons in 2010. Metallurgical coal consumption is projected to increase from about 117 million tons in 1993 to 172 million tons in 2010.

\section{China's Future Coal Consumption}

Figure 7, shows the estimated shares of coal consumption by sectors in 1993. The share of coal used for electricity generation has increased from 20 percent when China announced its open door policies in the late 1970s, to 36 percent in 1993. By 2010, 45 percent of China's coal consumption is expected to be for electricity generation.

The growth rates in coal consumption are quite different among the various coal consuming sectors in China. Figure 8 shows the projected change in coal consumption in China by sector over the $1993-2010$ period. The increasing 
dominance of coal use in the electricity sector is clearly shown in Figure 8. In contrast to a stagnant global metallurgical coal market, China's metallurgical coal consumption is projected to increase by 55 million tons over the 1993-2010 period.

For most coastal sites, base-load, coal-fired power plants are competitive with oil, natural gas, and nuclear power under the assumption that $\mathrm{SO}_{\mathrm{x}}$ control technologies are not employed. However, when $\mathrm{SO}_{\mathrm{x}}$ control technologies are added, the competitive advantage of coal is substantially reduced. Table 2 shows the breakdown of cost elements for a hypothetical coal-fired power plant located in Asia (excludes Japan where costs are much higher). ${ }^{3}$

Control technologies for particulates, $\mathrm{NO}_{\mathrm{x}}$, and $\mathrm{SO}_{\mathrm{x}}$ typically add $1.0-1.4$ $\notin / \mathrm{kWh}$ to the cost of generating electricity. This is roughly equal to the total cost of coal $(1.1-1.6 \notin / \mathrm{kWh})$. Table 2 shows that control costs vary widely depending on the pollutant being controlled. Particulate control, using electrostatic precipitators, adds only about $0.1 \mathrm{c} / \mathrm{kWh}$ and is not a significant cost factor. Moderate reductions in $\mathrm{NO}_{\mathrm{x}}$ emissions can be achieved by modifying the combustion process at costs of $0.1 / \mathrm{kWh}$ or less. High levels of $\mathrm{NO}_{\mathrm{x}}$ reduction, with selective catalytic reduction (SCR), adds about $0.3 \notin / \mathrm{kWh}$. As shown in Table 2, reducing $\mathrm{SO}_{\mathrm{x}}$ emissions by $90-95$ percent using flue gas desulphurisation (FGD), adds about $0.8 \mathrm{\&} / \mathrm{kWh}$ to electricity costs.

The relatively high costs of $\mathrm{SO}_{\mathrm{x}}$ control using existing technologies, causes most utilities to consider low sulfur fuels where these are competitively available, and allowed by legislation. The fossil fuel alternatives are switching to low sulfur coal, oil, or natural gas.

Internationally traded thermal coal in the Asian region typically has low sulfur contents of $0.5-0.8$ percent sulfur. There is probably substantial thermal coal available at lower sulfur contents in the $0.2-0.5$ percent range, and some coal with under 0.2 percent sulfur.

Assuming most governments set emission limits at medium levels in the 1990s, there appears to be sufficient internationally traded low sulfur coal to meet these emission standards. Beyond 2000, increasingly strict emission standards could change this assessment.

There is considerable uncertainty in projections of the markets for $\mathrm{SO}_{\mathbf{x}}$ control technologies over the 1993-2010 period. Japan will continue to meet the most stringent limits in the region, with high efficiency sulfur control technologies on all coal-fired power pants. Hong Kong, South Korea, and

\footnotetext{
${ }^{3}$ The capital costs of power plants vary widely from site to site. In addition, in China, power plants built with domestically manufactured technologies have capital costs of 40-60 percent of power plants with imported technologies.
} 
Chinese Taipei are likely to add sulfur control technologies to most new power plants. Thailand is expected to require sulfur control technologies on all plants using high sulfur domestic lignite, but may be more flexible for plants using imported low sulfur coal. Australia, China, India, Indonesia, and the Philippines are likely to more gradually introduce sulfur removal technologies.

Most industrialized economies have emissions limits between 400 and $2000 \mathrm{mg} \mathrm{SO} / \mathrm{m}^{3}$. Typical internationally traded coals contain $0.5-0.8$ percent sulfur, equal to emission levels of approximately $950-1,500 \mathrm{mg} \mathrm{SO} \mathrm{x}_{\mathrm{x}} / \mathrm{m}^{3}$. For comparison, the emission limits to be imposed in the United States in the year 2000 will limit emissions to a maximum of $1.2 \mathrm{lb}$. $\mathrm{SO}_{\mathrm{x}} / \mathrm{MBtu}$, equivalent to about 0.7 percent sulfur coal. The majority of Asian plants using imported coal, already meet $\mathrm{SO}_{\mathrm{x}}$ emission limits that utilities in the United States will not have to meet until $2000{ }^{4}$

However, China is projected to become the largest user of sulfur control technologies in Asia by about 2010. This is because China is by far the largest user of coal and burns medium to high sulfur coal in some areas, particularly in southern China (Sichuan Province). More than 50 percent of the coal burned in China's electric utility industry has sulfur contents greater than 1.0 percent.

Widespread use of imported, high efficiency sulfur removal technologies appears unlikely in China. The largest market in the medium term appears to be for lower cost, less efficient, domestically manufactured technologies. A number of foreign firms are already involved in or are considering joint ventures in China to produce lower cost sulfur control technologies. Imported high efficiency sulfur removal technologies are likely to be restricted to the most seriously polluted areas, and to selected high income coastal areas, where the higher electricity costs can be passed on to the consumer.

Based on electricity generation costs, low-sulfur coal is still the lowest cost option to reduce $\mathrm{SO}_{\mathrm{x}}$ emissions in most areas of Asia. However, utilities and governments need to consider a number of other factors that can tip the balance toward sulfur control technologies (referred to here as Clean Coal Technologies or CCTs). These include: (1) greater public acceptance of plants with CCTs; (2) plants using CCTs can be located close to the users, providing greater opportunities to use the waste heat (substantially increases overall efficiency); (3) environmental legislation is becoming stricter, and utilities can reduce future uncertainty by installing CCTs with new plants; (4) development banks (such as the World Bank and Asian Development Bank) are tightening the environmental performance standards for projects they will finance; and (5) it is

\footnotetext{
${ }^{4}$ The U.S. Clean Air Act has numerous requirements and is more complicated than indicated here.
} 
difficult for governments to require their own cash-short state utilities to install CCTs, but may be easier to require private power companies, particularly foreign companies, to install CCTs.

Control of $\mathrm{CO}_{2}$ emissions from fossil fuel burning is too expensive to be considered as a competitive option at this time. With respect to coal use, increased efficiencies through advanced CCTs can reduce $\mathrm{CO}_{2}$ emissions per unit of electricity. The increasing efficiencies in electricity generation in Asia is likely to reduce but not eliminate the growth rate in $\mathrm{CO}_{2}$ emissions over the 1993-2010 period. Beyond about 2005, advanced CCTs, such as integrated gasification combined cycle (IGCC), are promising for both reducing traditional pollutants, and substantially reducing $\mathrm{CO}_{2}$ emissions per unit of electricity.

\section{Projections of Production, Consumption and Trade}

Table 3 shows coal production and consumption in Asia in 1993. In 1993 Asia produced and consumed about 1.7 billion tons of coal. Coal production in Asia is highly concentrated, with China, India, and Australia accounting for 95 percent of the region's production. With respect to consumption, China, India, and Japan account for almost 90 percent of the region's coal consumption.

Coal consumption in Asia is projected to increase at 3.7 (range 3.4-3.9) percent per year over the 1993-2010 period. Assuming an average growth rate of 3.7 percent per year, consumption is projected to increase from 1.7 billion tons in 1993 to 3.1 billion tons in 2010 - an 85 percent increase. Figure 9 shows the projected growth in consumption for the economies with the largest growth. China and India are expected to account for over 80 percent of the growth in coal consumption in Asia. Indonesia, which presently consumes only 10 million tons of coal per year, is projected to increase consumption by almost 60 (range 45-70) million tons over the 1993-2010 period.

Figures 10 and 11 show projected net coal trade in Asia over the 19932010 period. In Figure 10, South Korea is projected to edge by Japan and record the largest increase in imports over the 1993-2010 period. Projected net imports to the Philippines and Thailand could be off by more than 30 percent, and more than 100 percent for India and North Korea.

Figure 11 shows the continued dominant export position of Australia over the 1993-2010 period. Australia's share of net Asian exports is projected to decrease from 78 percent in 1993 to $70-75$ percent in 2000 and then gradually increase to 76-79 percent in 2010. The expected decline in Australia's share of net exports over the next 5-10 years is due to rapid expansions in Indonesian exports. Although China is expected to increase exports to $40-50$ million tons 
per year by 2010, imports of coal are projected to reduce net exports to 20-30 million tons per year by 2010 .

\section{Conclusions}

The role of coal in Asia is greater than in any other region of the world. Although China is the most important factor contributing to the greater importance of coal in Asia's energy mix, coal is used widely in Asia, particularly for electricity generation. Coal consumption is projected to grow at 3.7 percent per year from 1.7 billion tons in 1993 to 3.1 billion tons in 2010 .

The environmental consequences of the projected increases in coal consumption are serious in some parts of Asia. The trend in Asia is toward more stringent environmental regulations pertaining to particulate, $\mathrm{SO}_{\mathrm{x}}$, and $\mathrm{NO}_{\mathrm{x}}$ emissions, however most utilities in developing economies of Asia are relying heavily on the use of low sulfur coals to meet $\mathrm{SO}_{\mathbf{x}}$ emission standards. Due to their relatively high costs and the availability of low sulfur coal, sulfur control technologies are being introduced gradually in most Asian economies. With respect to reducing $\mathrm{CO}_{2}$ emissions, most governments are unlikely to take substantive action to restrict coal use in the 1990s.

China accounts for more than 70 percent of Asia's $\mathrm{SO}_{\mathrm{x}}$ emissions, but is unlikely to adopt high efficiency sulfur removal systems on a wide scale during the 1993-2010 period. Substitution of low sulfur fuels and lower cost, less efficient, domestically produced sulfur control technologies are likely to dominate the Chinese market. However, the large size of China's coal-fired capacity will result in China becoming the largest user of sulfur control technologies in Asia within 20 years. 


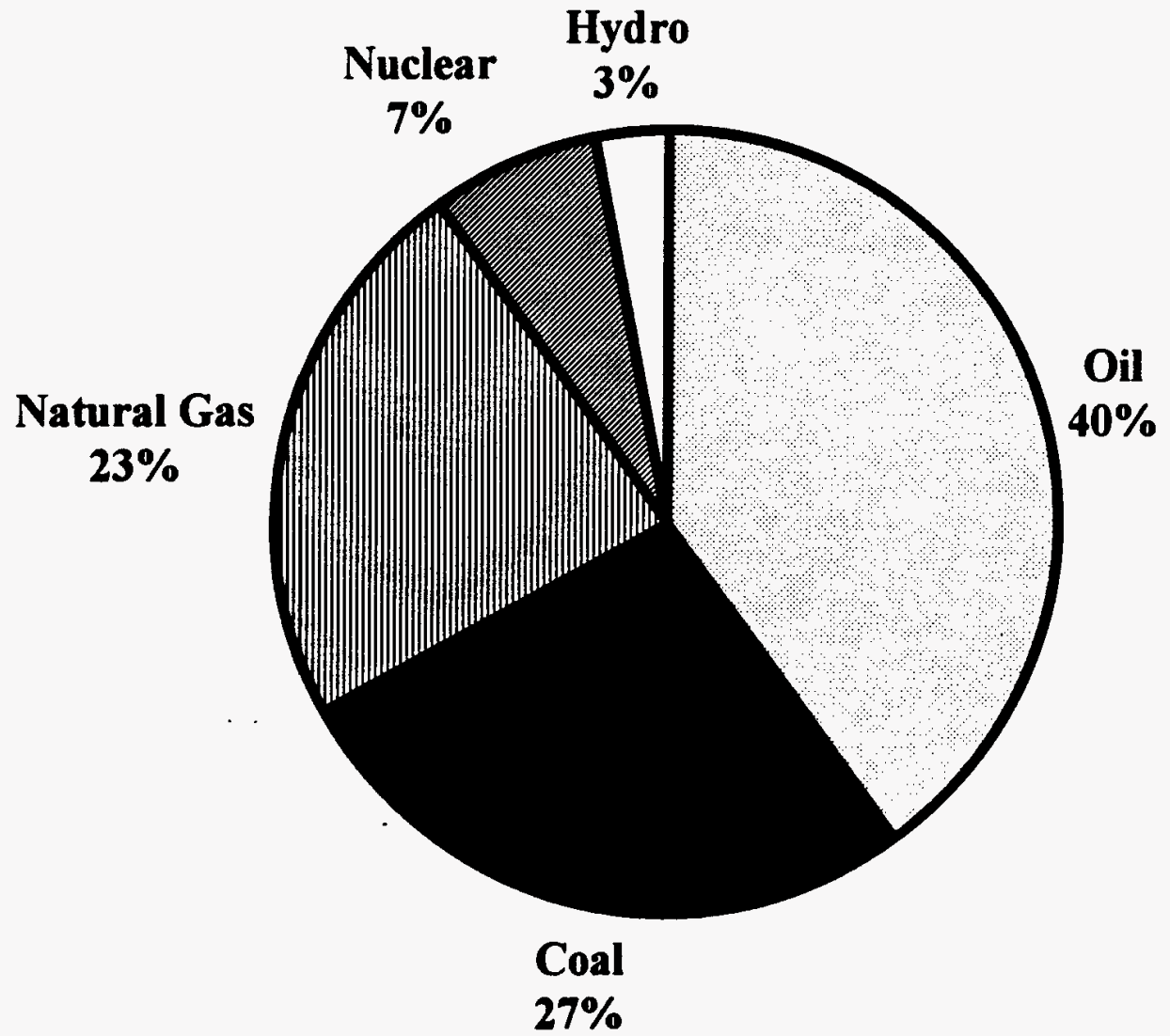

Figure 1. Primary Energy Shares in the World in 1993

Source: BP Statistical Review of World Energy, 1994 


\section{Asia}

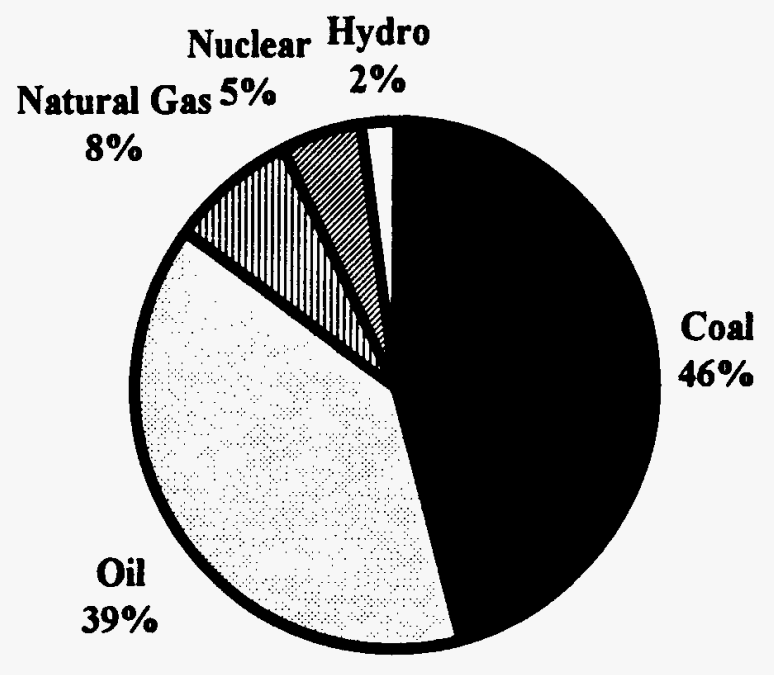

World Excluding Asia

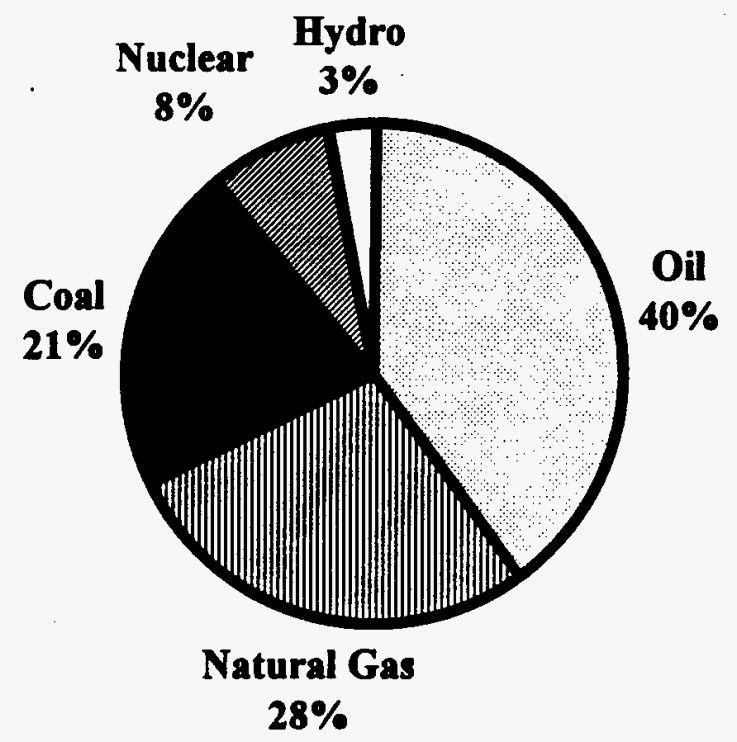

Figure 2. Primary Energy Shares in Asia and the World excluding Asia in 1993

Source: BP Statistical Review of World Energy, 1994 


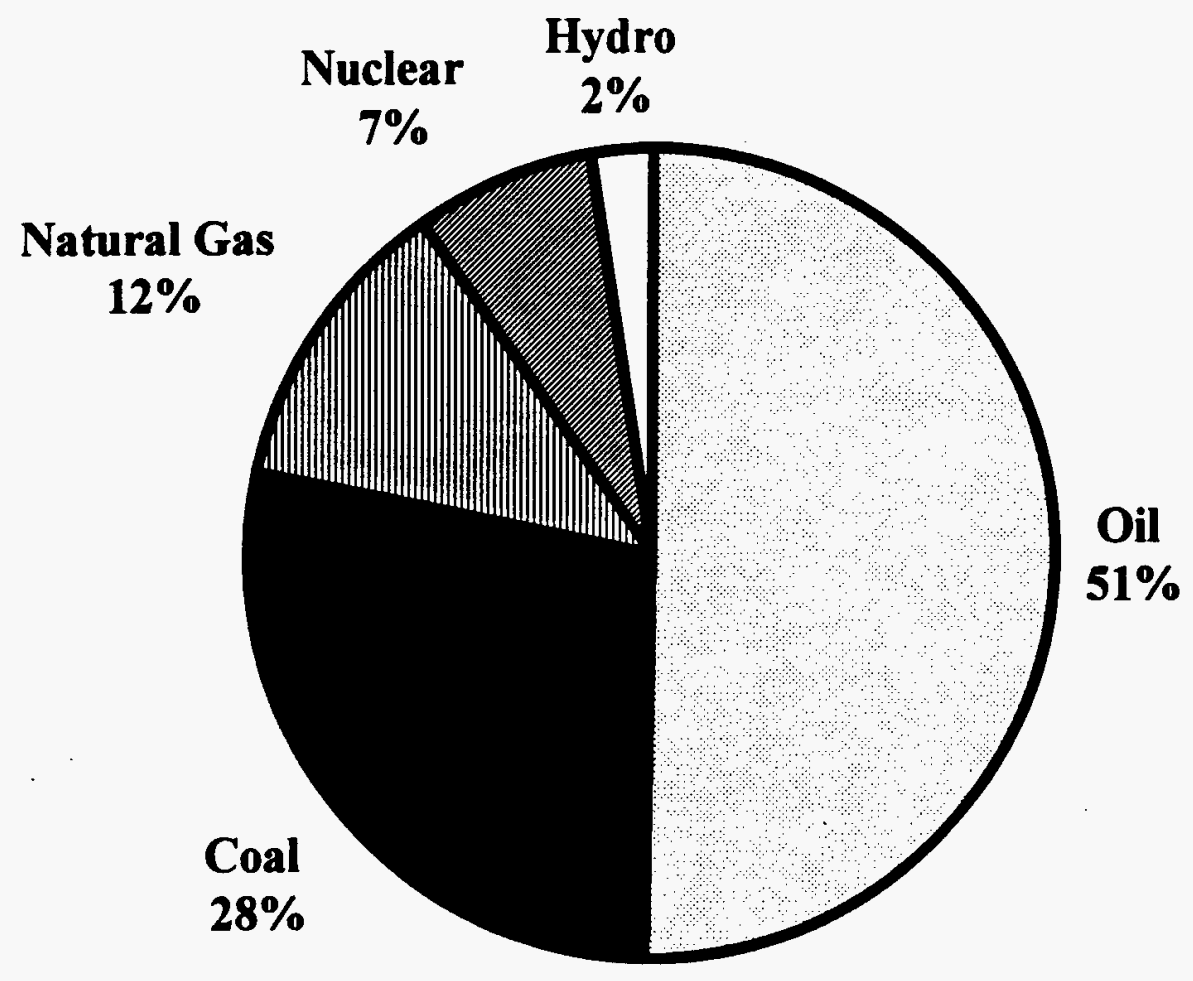

Figure 3. Primary Energy Shares in Asia Excluding China in 1993

Source: BP Statistical Review of World Energy, 1994 


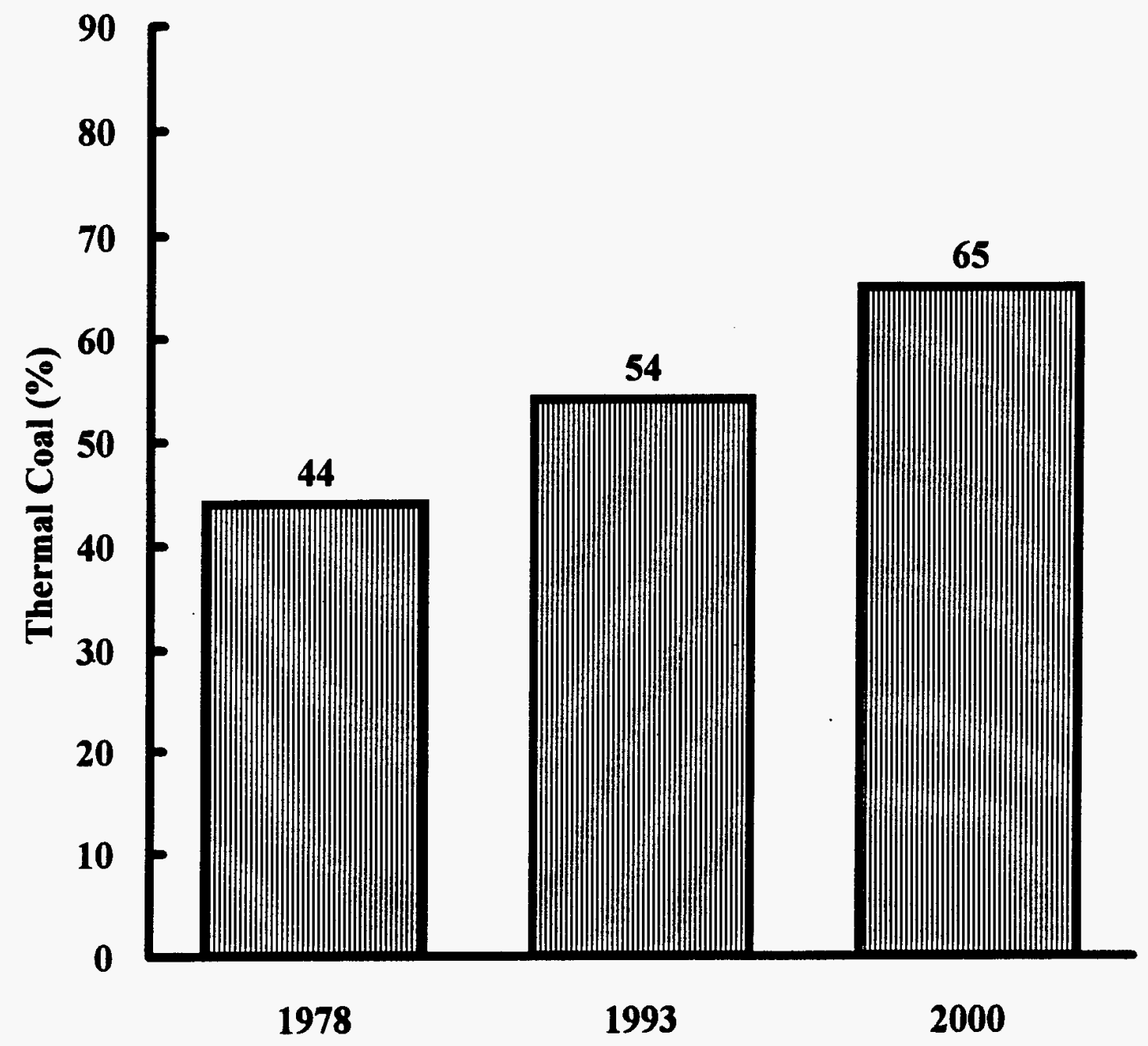

Figure 4. The Increasing Share of Thermal Coal in International Coal Trade 


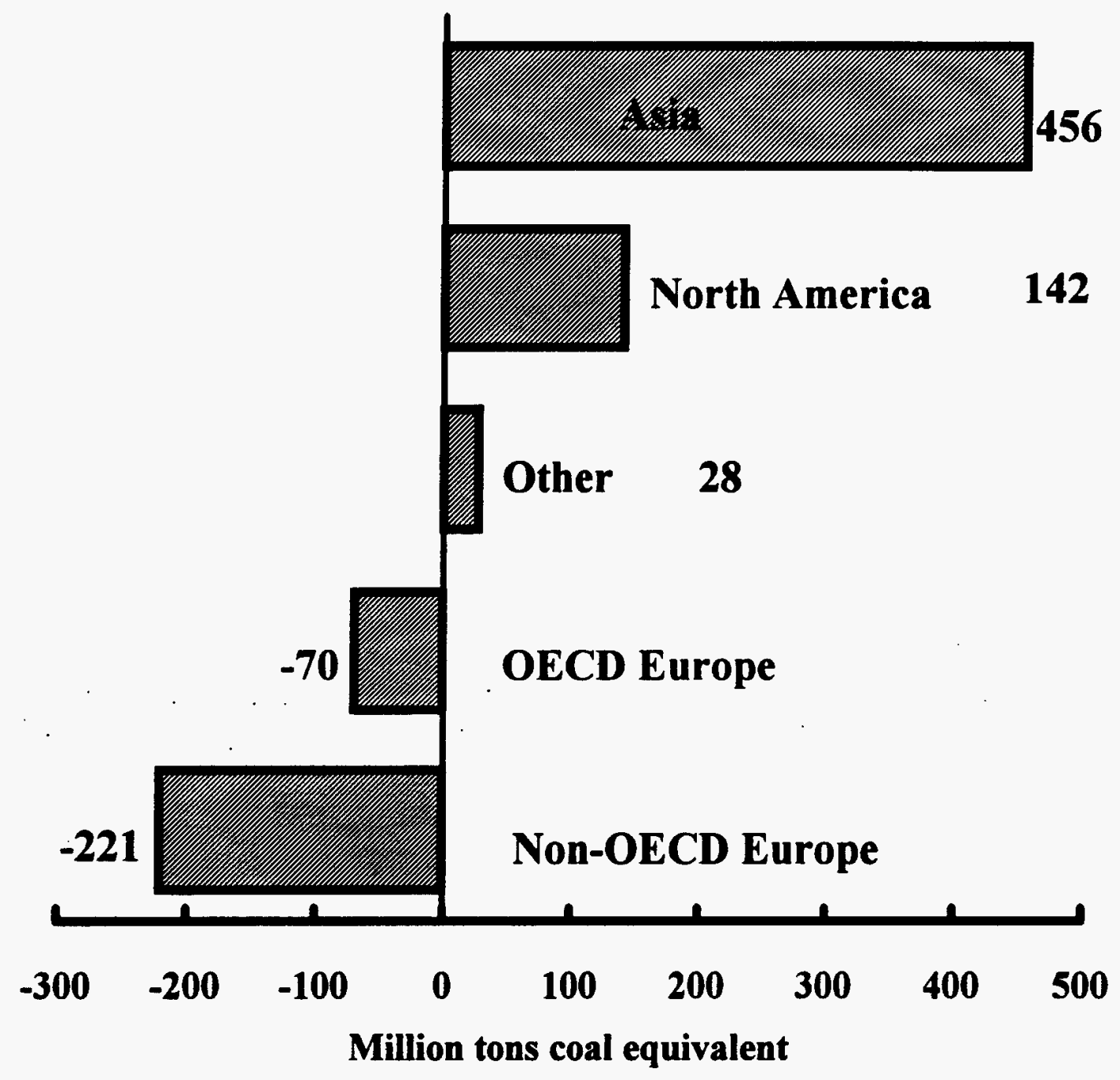

Figure 5. Regional Changes in Coal Consumption: 1983-1993 
Table 1. GDP, Electricity and Elasticities in the 1980s

\begin{tabular}{||l|c|c|c||}
\hline \hline & $\begin{array}{c}\text { GDP Growth } \\
(\% / \text { Year })\end{array}$ & $\begin{array}{c}\text { Electricity Growth } \\
(\% / \text { Year })\end{array}$ & $\begin{array}{c}\text { Electricity } \\
\text { Elasticity }\end{array}$ \\
\hline China & 9.2 & 7.5 & 0.82 \\
Japan & 4.2 & 4.0 & 0.95 \\
Taiwan & 7.7 & 8.1 & 1.05 \\
S.Korea & 8.3 & 11.5 & 1.39 \\
Hong Kong & 7.0 & 8.6 & 1.23 \\
Thailand & 7.6 & 11.8 & 1.55 \\
Australia & 3.1 & 4.9 & 1.58 \\
Malaysia & 6.2 & 9.3 & 1.50 \\
India & 5.8 & 9.1 & 1.57 \\
New Zealand & 1.9 & 3.2 & 1.68 \\
Indonesia & 6.0 & 12.0 & 2.00 \\
Philippines & 1.9 & 3.9 & 2.05 \\
\hline \hline
\end{tabular}

Source: Coal Information 1992, International Financial Statistics, and UN

Energy Statistics Yearbooks, 1983-1990. 


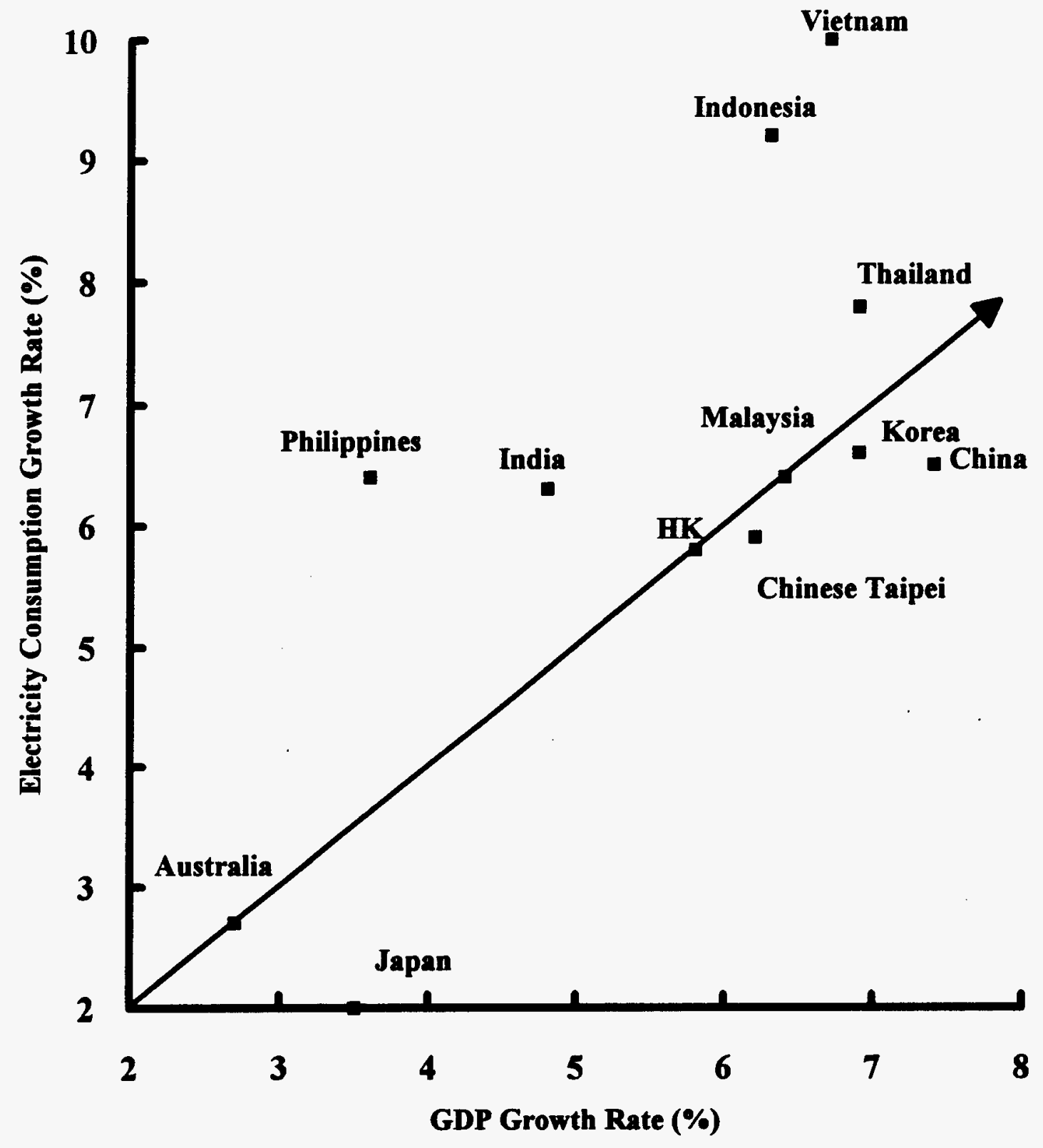

Figure 6. Projected Electricity Growth Rates and GDP: 1993-2010 


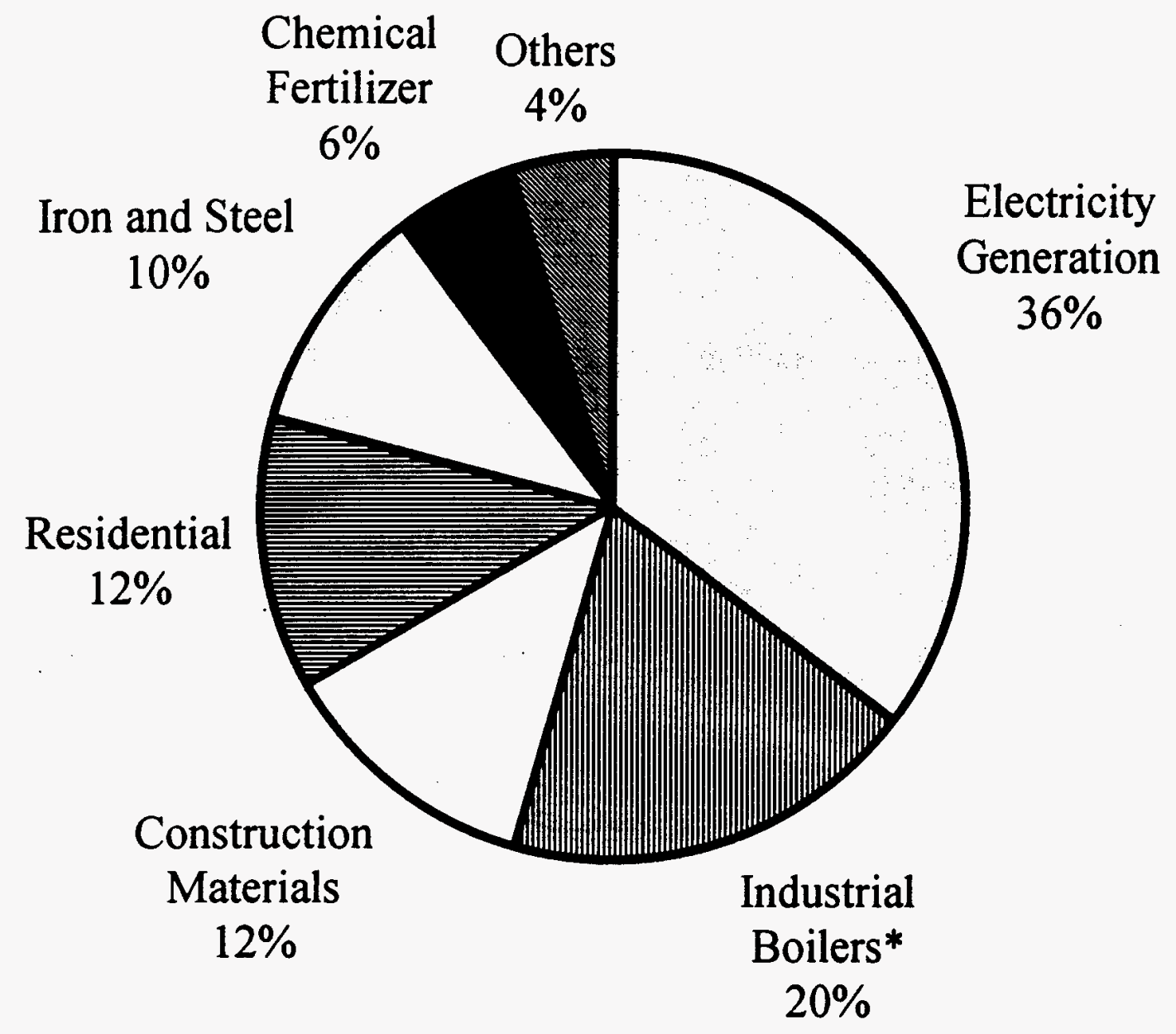

Figure 7. China's coal consumption by sector in 1993

* Excluding the chemical, iron and steel, and construction materials industries. 


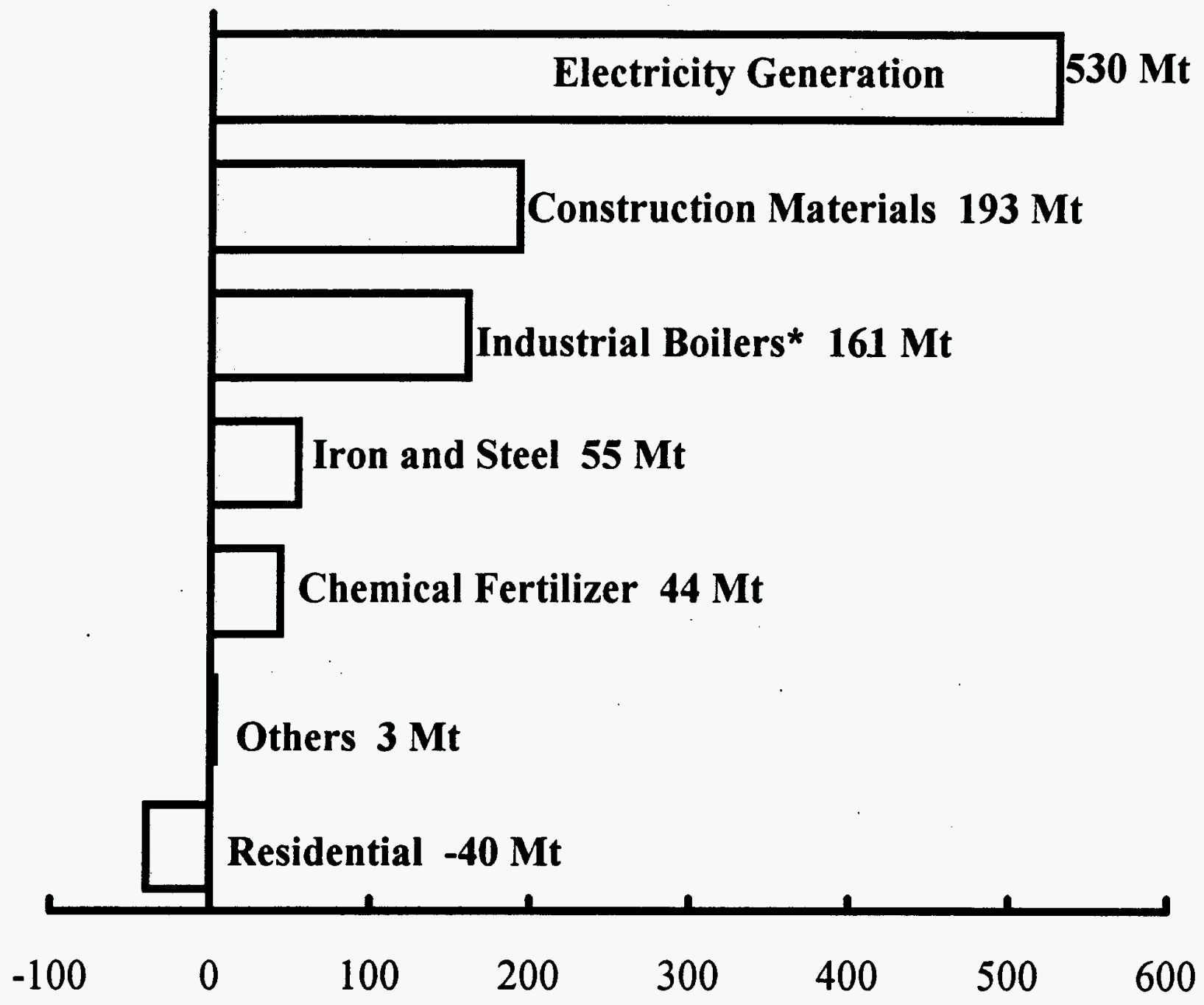

Figure 8. Projection of China's sectoral coal consumption changes: 1993-2010.

* Excluding the chemical, iron and steel, and construction materials industries. 
Table 2. Components of Electricity Generation Costs for a Coal-Fired Power Plant in Asia

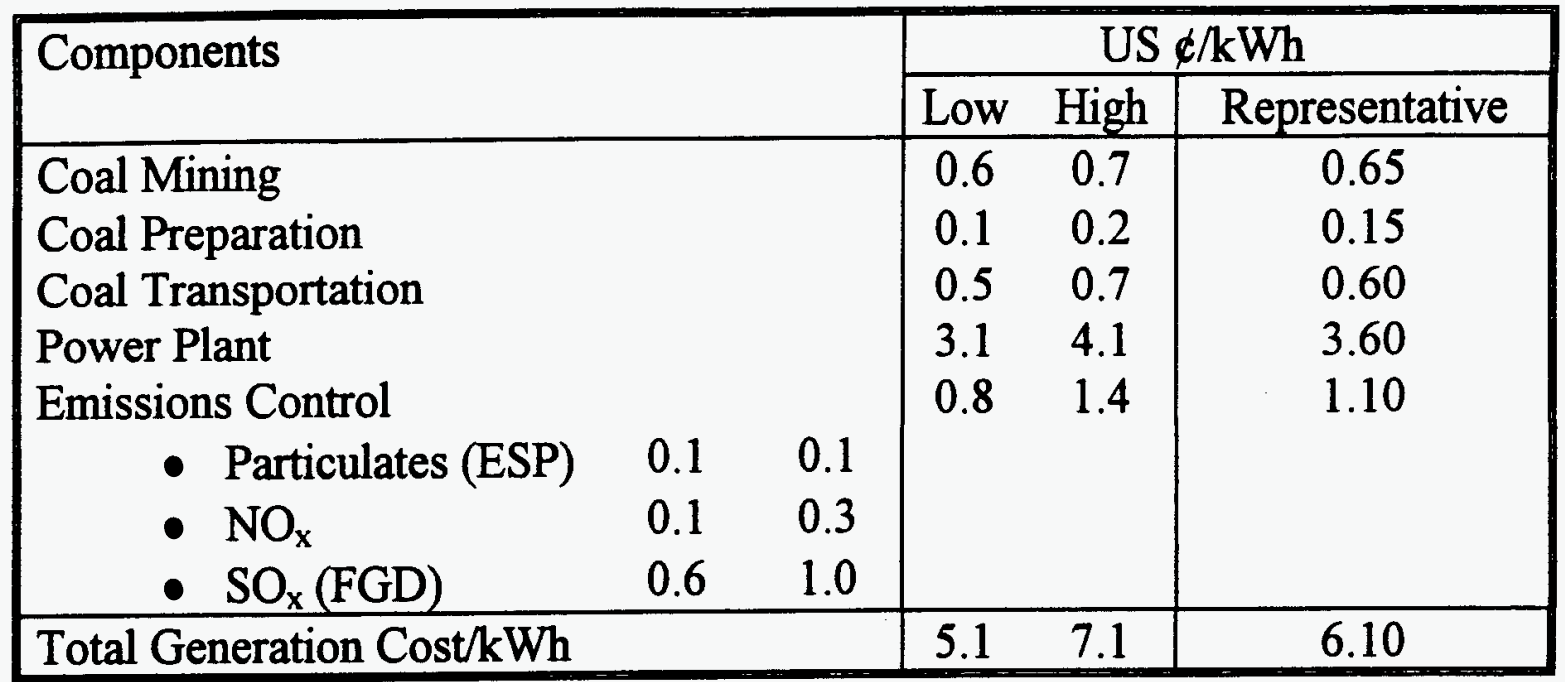

Note: Estimates are for a hypothetical coal-fired plant importing coal by sea; excludes land cost and taxes. There are costs above and below the range shown and the weighted costs of all projects are unknown. 
Table 3. Coal Production and Consumption in Asia in $1993^{1}$

(million metric tons )

\begin{tabular}{|l|c|c|}
\hline & Production & Consumption \\
\hline Australia & 185 & 53 \\
China & 1141 & 1123 \\
Chinese Taipei & 0 & 25 \\
Hong Kong & 0 & 12 \\
India & 149 & 257 \\
Indonesia & 28 & 10 \\
Japan & 7 & 118 \\
North Korea & 34 & 35 \\
South Korea & 9 & 40 \\
Philippines & 2 & 3 \\
Thailand & 0 & 2 \\
Vietnam & 5 & 3 \\
Other & 6 & 9 \\
\hline Total & 1666 & 1690 \\
\hline
\end{tabular}

${ }^{1}$ Asia includes Australia but excludes Russia; lignite is excluded. 


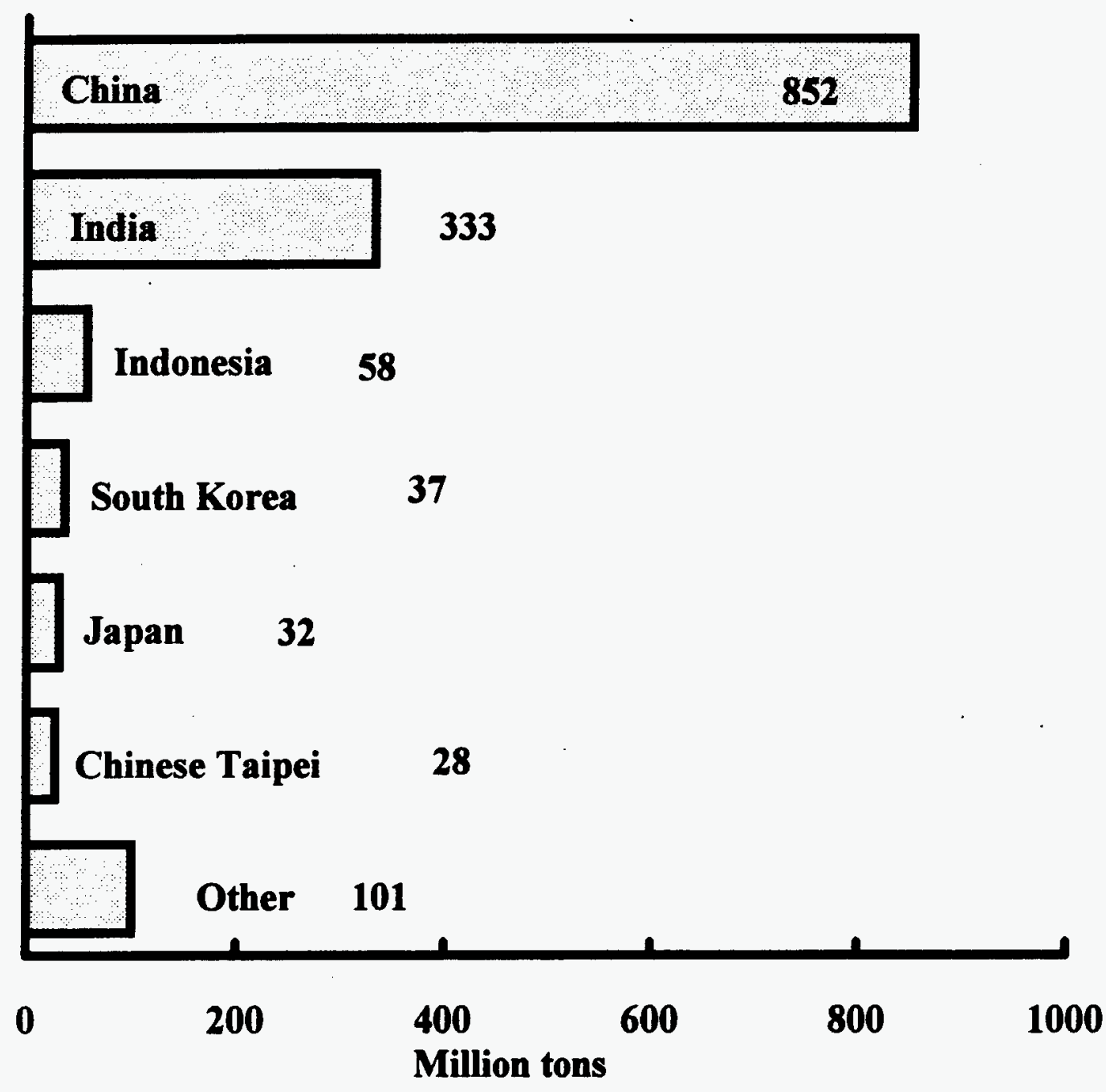

Figure 9. Projected Increase in Coal Consumption: 1993-2010 


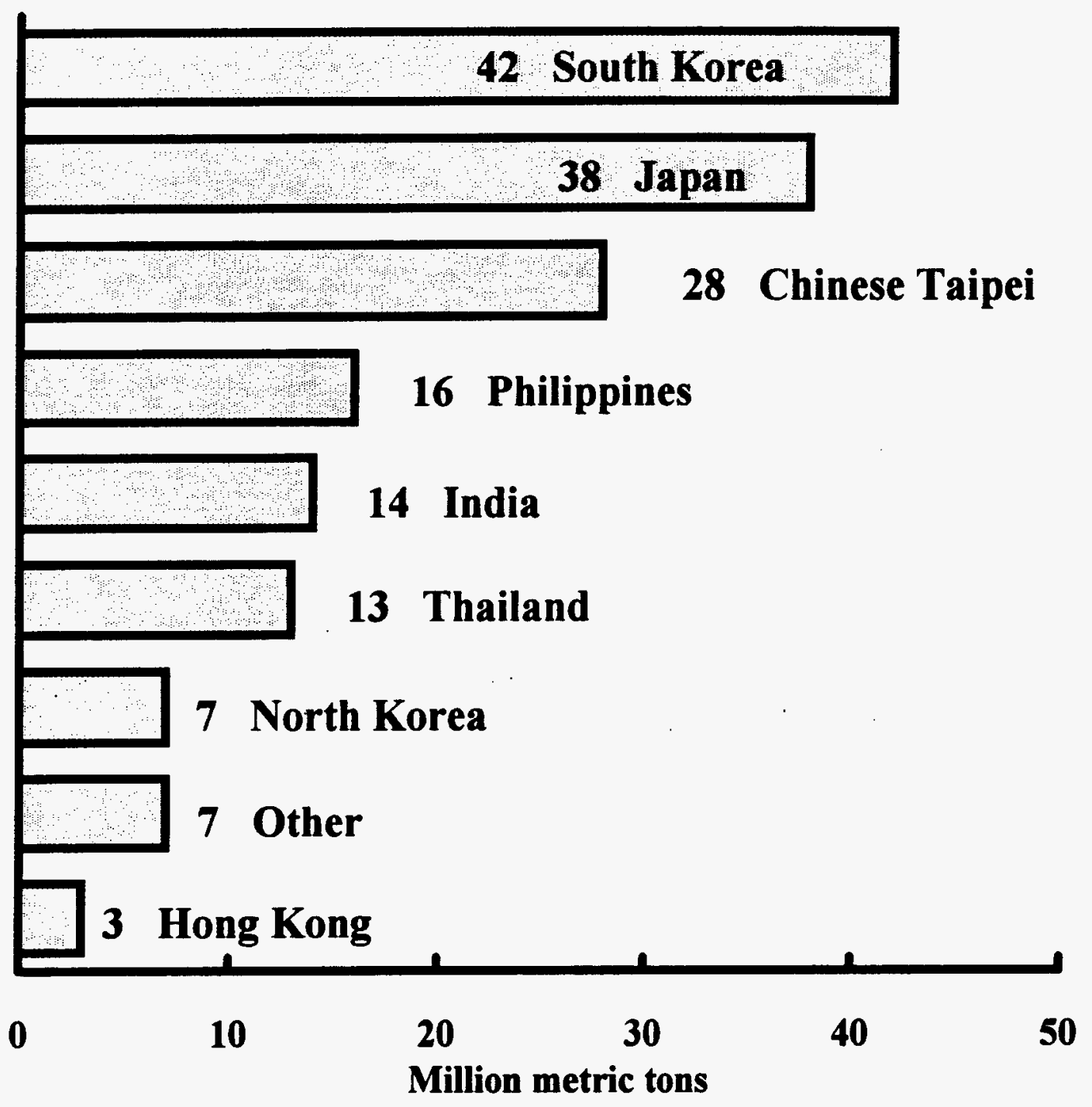

Figure 10. Projected Increase in Net Imports: 1993-2010 


\section{Indonesia}

7. China

5 Vietnam

$\begin{array}{llcccc}0 & 20 & 40 & 60 & 80 & 100 \\ & & \text { Million metric tons } & & \end{array}$

Figure 11. Projected Increase in Net Exports: 1993-2010 
Table 1. Annual Average Sulfur Dioxide Concentrations in Selected

Chinese Cities in 1991 ( $\mu \mathrm{g} /$ cubic meter)

\begin{tabular}{|c|c|c|c|c|c|c|c|}
\hline NO. & City & $\begin{array}{l}\text { North } \\
\text { Province } \\
\end{array}$ & Emissions & NO. & City & $\begin{array}{l}\text { South } \\
\text { Province } \\
\end{array}$ & Emissions \\
\hline 1 & Taiyuan & Shanxi & 277 & 1 & Chongqing & Sichuan & 351 \\
\hline 2 & Urumqi & Xinjiang & 207 & 2 & Guiyang & Guizhou & 341 \\
\hline 3 & Qingdao & Shandong & 204 & 3 & Yibin & Sichuan & 305 \\
\hline 4 & Shijiazhuang & Hebei & 162 & 4 & Nancong & Sichuan & 239 \\
\hline 5 & Baotou & Inner Mongolia & 142 & 5 & Changsha & Hunan & 173 \\
\hline 6 & Tianjin & Tianjin & 142 & 6 & Yichang & Hubei & 165 \\
\hline 7 & Shenyang & Liaoning & 137 & 7 & Hangzhou & Zhejiang & 122 \\
\hline 8 & Jinan & Shandong & 135 & 8 & Shanghai & Shanghai & 99 \\
\hline 9 & Datong & Shanxi & 134 & 9 & Guilin & Guangxi & 85 \\
\hline 10 & Beijing & Beijing & 122 & 10 & Fuzhou & Fujian & 82 \\
\hline 11 & Zibo & Shandong & 121 & 11 & Xuzhou & Jiangsu & 81 \\
\hline 12 & Anshan & Liaoning & 104 & 12 & Guangzhou & Guangdong & 70 \\
\hline 13 & Shizuishan & Ningxia & 104 & 13 & Chengdu & Sichuan & 66 \\
\hline 14 & Lanzhou & Gansu & 102 & 14 & Suzhou & Jiangsu & 65 \\
\hline 15 & Yuncheng & Shanxi & 89 & 15 & Hengyang & Hunan & 62 \\
\hline 16 & Zhengzhou & Henan & 86) & 16 & Wenzhou & Zhejiang & 61 \\
\hline 17 & Tangshan & Hebei & 86) & 17 & Nantong & Jiangsu & 50 \\
\hline 18 & Anyang & Hebei & 79 & 18 & Nanning & Guangxi & 50 \\
\hline 19 & Jilin & Jilin & 75 & 19 & Nanjing & Jiangsu & 50 \\
\hline 20 & Dalian & Liaoning & 75 & 20 & Huaihua & Hunan & 47 \\
\hline 21 & Xian & Shaanxi & 68 & 21 & Hefei & Anhui & 46 \\
\hline 22 & Changchun & Jilin & 61 & 22 & Liupanshui & Guizhou & 46 \\
\hline 23 & Yanan & Shaanxi & 60 & 23 & Kunming & Yunnan & 45 \\
\hline 24 & Yinchuan & Ningxia & 56 & 24 & Baise & Guangxi & 45 \\
\hline 25 & Baoji & Shaanxi & 54 & 25 & Ganzhou & Jiangxi & 44 \\
\hline 26 & Xining & Qinghai & 51 & 26 & Nanchang & Jiangxi & 41 \\
\hline 27 & Hanzhong & Shaanxi & 50 & 27 & Gejiu & Yunnan & 41 \\
\hline 28 & Qinhuangdao & Hebei & 45 & 28 & Xiangfan & Hubei & 40 \\
\hline 29 & Pingdingshan & Henan & 43 & 29 & Wuhan & Hubei & 40 \\
\hline 30 & Hohhot & Inner Mongolia & 35 & 30 & Zhanjiang & Guangdong & 37 \\
\hline 31 & Jiayuguan & Gansu & 35 & 31 & Sanming & Fujian & 25 \\
\hline 32 & Tumen & Jilin & 28 & 32 & Anqing & Anhui & 21 \\
\hline 33 & Harbin & Heilongiiang & 27 & 33 & Shenzhen & Guangdong & 16 \\
\hline 34 & Daqing & Heilongjiang & 15 & 34 & Xiamen & Fujian & 8 \\
\hline 35 & Hegang & Heilongiiang & 13 & 35 & Haikou & Hainan & 4 \\
\hline
\end{tabular}


Report Number (14) CONF-9410333--1

Publ. Date (11) Doe 199410
Sponsor Code (18)
UC Category (19) $U C-101$, DOE ER

mo1332,15 in folden

\section{0}

DITCQUATII INOPECIEDI

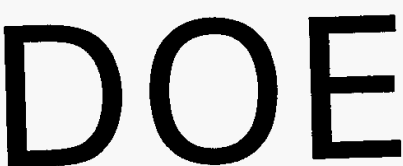

